$\mathbb{T}$ periodica polytechnica

\author{
Architecture \\ 41/1 (2010) 27 33 \\ doi: 10.3311/pp.ar.2010-1.04 \\ web: http://www.pp.bme.hu/ar \\ (c) Periodica Polytechnica 2010 \\ RESEARCH ARTICLE \\ András Szalai \\ Received 2009-08-31
}

\section{Lajos Fülep: On Art and Architecture}

\begin{abstract}
Fülep, Lajos (1885-1970) - Hungarian philosopher, art historian. One of the dominant, though partly forgotten, figures in $20^{\text {th }}$ century Hungarian art philosophy and art history. Some experts regard his oeuvre as a being dated, and for this reason consider it unnecessary to study his work however there are a number who consider him "the creator of modern Hungarian art history", and the real founder of the methodological approach called "Kunstgeschichte als Geistesgeschichte" (art history as the history of ideas/spirit), even preceding the works of Max Dvořák in this field. This paper looks at his writings on architecture and on art philosophy related to architecture. The titles in order of appearance: The role of the memory in the artistic creation (1911), Hungarian Architecture (1918), Expedience and art in the architecture (1944), A great opportunity in the rebuilding of Budapest and the country (1948).
\end{abstract}

\section{Keywords}

art philosophy $\cdot$ architectural theory $\cdot$ Hungarian art $\cdot$ Hungarian architecture

\section{András Szalai}

Department of for History of Architecture and of Monument Preservation, BME, H-1521 Budapest Múegyetem rkp. 1-3., Hungary

e-mail:
Lajos Fülep (1885-1970) art historian and art philosopher, is a dominant figure in Hungarian art philosophy of the $20^{\text {th }}$ century, who compared to the significance of his oeuvre, has been somewhat forgotten.

There are some who consider his ideas and theories out of date and discredited, and for this reason they do not find it important to acquire a deeper knowledge of his thoughts. But others, of whom there are fewer, are of the opinion that he was actually "the creator of modern Hungarian art history" and at the same time the real founder of "Kunstgeschichte als Geistesgeschichte", preceding the work of Max Dvořák that was developing in the period around 1910 [15].

It might be a belated question today whether the matter, namely the priority of the approach of "art history as the history of spirit" is true or false, which could not be or should not be answered; notwithstanding, it is (or it might be) also a relevant question to be discussed and proved. Just as it is also of great importance to ensure it be known that even in international terms, Fülep was one of the first ones who understood the revolutionary relevance of Cézanne's painting, or that he was an internationally recognized expert on Dante [3, 5, 8].

Besides this, he was a great authority on the philosophy of Nietzsche and Bergson, and early on he became an appreciative critic of the aesthetics of Benedetto Croce. The title of his essay on this subject: The role of the memory in the artistic creation, was written and first published in Italian 1

Though the topic of his essay on the philosophy of art goes beyond architecture, his theory on the quality of forming, i.e. producing a form, creating something, and the function of the productive memory is tightly connected to the issue of architectural expression and formation. His posing of memory has risen in a polemic context; his statements reflect the thesis mentioned in the influential work "Aesthetic" written by Benedetto Croce [1].

According to Croce knowledge has two forms: "it is either intuitive knowledge or logical knowledge; knowledge obtained through the imagination or knowledge obtained through the intellect; knowledge of the individual or knowledge of the univer-

$1 \sqrt[6]{ }$, the discussion in relation with the lecture: [7]. 
sal; of individual things or of the relations between them: it is, in fact, productive either of images or of concepts. (...) intuitive knowledge is expressive knowledge. (...) intuition or representation is distinguished as form from what is felt or suffered, from the flux or wave of sensation, or from physical material; and this form, this taking possession of, is expression. To have an intuition is to express. It is nothing else (nothing more but nothing less) than to express.' [2, pp.241-242],[16]

However, according to Fülep, the aesthetics of Croce did not re-integrate the understanding of the artist's creativity into the completeness of the normal psyche, and later he did not properly differentiate it within the field of creativity. He also criticizes Croce's understanding of the role of intuition which states that: on the one hand art is intuition and nothing else, on the other hand intuition is identical with the expression, and consequently all kinds of expression are artistic activities. While Fülep states: "Intuition creates nothing from nothing. The thing which places the objects is memory (or reality in case of perception), so objects are the products of memory and not intuition." [7. p. 611]

Regarding the relationship between memory and expression, he explains that along with the expression of things in the past, expression of things in the present also works as a kind of recollection, and all intuition appearing in the present has to be changed into recollection in order to be expressible, and to turn into art. "In other words, in the complex phenomenon called recollection the attendant emotion has to have the same fate as the image generating it: emotion first has to become intuition, intuition must turn into recollection for making recollection become expression in the end.' 2

On the basis of the above, Fülep defines his proposition against the statement of Croce, namely that intuition is expression: "every expression is recollection". But there is no art without intuition, since the artist can only remember the characteristics that he was able to see. At the same time, the artist submits his feelings and intuition to the selection - which can be both an automatic and an intended action - which is executed by recollection.

The emotion, the state of mind, which can be considered as a source of intuition, is one and undividable, continuous, unlimited, with no start and no end; it can be described with indivisibility, unity, qualitative multiplicity. Though the expression in the end of the artistic forming process is non-continuous, it has a start and an end, it consists of elements and quantities next to each other, and not only the exterior-originated (extrinsecus) expression coming from outside possesses these features.

\footnotetext{
2 [7. p. 612]; - the second part of the quotation: "Intuition is always related to present, but present can never be expressed: we always express a vanished state of mind, and at the time as we express it, present connects a new state of mind to it, which becomes at that moment past again to be expressible, and so on till the end of time - and the expression can never get free from the past and recollection and can never be directly united with the intuition of the present state of mind."
}

There is a complete contrast between the continuous state of mind and the non-continuous quantities, and the quantitative concept of space and time; nevertheless, only these quantitative, non-continuous notions make it possible to express. These quantitative, non-continuous notions and elements actually divide the undividable part of memory, the inner spiritual life; thus they make it possible to place next to each other and to observe things far from one another in time or to examine those coherent things separately. "Our recollection divides past, the motionless time to parts and phases; turns the quality of the states of mind and intensities into quantities, in order to operate with them." [7. p. 625]

For example, the motionless (past) time can only be seized through the idea of space, and for this the clearly spatial ideas of "back" and "forth" are essential. But in relation to this, there is much more here than our idea of space intruding our concept of time, as it is claimed by Bergson, since it is quite true that the concept of time cannot be imagined without the notion of space at all. All moments before and after, meaning remembrance and prevision, are at smaller or greater distances from the present.

Fülep states "The present is: continuity, but for this continuity to become conscious in me I need the inner vision of space, for the things in front of and behind me; present is continuity but it only becomes conscious with the contrast of incontinuity. Where only continuity exists it can never be conscious. Where there is only succession (durée) it cannot be conscious. The moments of present are undividedly interlaced in continuity like the points of motion; they only become conscious by recollection, which is based on space and operates with incontinuity.” [7, p. 626]

The ideas of physical space and time are also important in the creation of the artistic form, just as the extension and duration meaning the content (durée) - are also essential. Extension and duration (durée) are the contents of the direct approach, while absolute space and time are part of the memory. In order to create the expression (and the artistic form), the first, extension and succession/durée, have to go through the second, through absolute space and time. Only in this way, namely with the help of quantitative qualities, can the extension and succession, unity and continuity be created again within the artistic form, with a different character from the real(ity). That is to say that the pure quality being an undivided state of mind is divided and becomes quantity, after that, within the form the quantity turns into quality again and becomes a whole again.

Consequently, the ideas of space and time play an important role in expression. But at the same time, it is also necessary to emphasize that the expression is never equal to the direct intuition of the mind - the emotion which gives the starting point of the process, but it is rather a summary, synthesis, symbol of that emotion.

In relation with art and artistic expression, some relevant consequences can be drawn from the above. One of them, in the light of these thoughts is that artistic imagination is not the talent of reaching away from reality, but the form exceeding reality. 
Recollection, this productive ability of the intellect, can be distinguished from reality by a "certain form", namely the artistic form.

Also in the context of language, artistic form is a significant criterion: "we acquire the notions from the elemental, unexpressed intuitions (images); and from notions we can get the appropriate term, the words. And only after we have found the expression for the general, the notion, can we arrive at the expression of individual intuition. That is why art is the complete contrast of mere language, art starts where language ends... , 3

Above all, there is a much more important conclusion or consequence, namely that the most relevant factors in art, which are form and composition, can really be interpreted in this concrete theoretical context - i.e. the origin of art is the memory. When man transfers the sensations of "the runaway present" into form, he not only preserves them but also sets himself free from them.

"The same thing that the average man does with simple statement and the religious one with confession, the poet and artist do when they form: they are remembering but at the same time they set themselves free from the experiences of the past.." 4

However, the act of forming is similar to this process even when the composing is not intended to be this liberator/emancipator, confession-like action. When the formcreating, composing recollection is deliberate, then the concrete, clear and final contour of the form evolves only step by step from the obscure, wreathing and liquid state. In art, just as in recollection in general, the forming and composing effort is focused on raising the final form out of the chaotic context of reality - of nature.

Nature is typical of its kaleidoscope-like variety; there is nei-

$3 \sqrt{7}$. p. 630]. Some conclusions can be drawn from this statement. One of them is that without notions the formal expression is impossible, seemingly the basic or pre-condition of the form would be the notion emerging from the context of language. At the same time, this does not come from the context of the whole train of thoughts, or even if this is the conclusion, it is much more important that the artistic form is not really the consequence of the notion: "art (...) starts where language has ended."

${ }^{4}$ [7. p. 633]; it is worth to quote a longer part of this train of thoughts (pp. 633-634.): "When the fact of recollection is intended and not accidental or automatic, so when with several attempts and concentration we are able to follow the stages of its development and we can analyze it, then (and I believe with this description I interpret the experiences of many of us) we can see a specific fog, atmosphere or chaos with blurry, wobbling and uncertain boundaries thus we can't see the desired form completely at the very first instance (...) later we perceive the whole figure in different situations (...) finally in the straggle against the atmosphere intruding and dissolving the contours of the figure we construct the whole figure by pealing and clearing off the chaos - and in this way we get the complete figure with its sharp contours, lines and forms. (...) Similarly to the sculptor when he cuts away the surplus from the marble block and leaves the essential, the figure that was hidden in the block." On the one hand these words are in harmony with the general experience of form-creators; and on the other hand it is concordant with the message of for example Peter Zumthor when he says in the film on the thermal bath of Vals the following about the planning of the building: first the building was blurred but its complete image has been (virtually) unchanged during the planning process and it has become sharper, more exact and detailed by time. ther a centre nor a favoured point of view in it: "there are only details in nature, which are surrounded by infinity; on the other hand, art gives not the details but totalities, closed unities, independent completeness, from which the physical infinity and mere nature are excluded."

At the same time, recollection has a double character; Fülep expresses it as "we are not only conserving impressions and experiences, but incessantly forming and composing with them. This is because it is easier to remember the formed and composed things than the informed ones." [7, p. 635]

As another consequence, we can only talk about artistic form where the sensation and cognition of form-creating activity is present. The concept and feeling of beauty makes it possible to seize the aesthetic fact and content within the form-creating activity. In the aesthetic experience, the cognition, the theoretic momentum is only the preparatory stage.

The emotional momentum is of a great importance in the artistic forming - "the feeling which enjoys the form, independent from the content". And this emotional momentum or feeling, contrary to the intellectual and moral activities, is not a mere attendant of the artistic activity states Lajos Fülep.

After this, he emphasizes in his typical manner: "in art-and for aesthetics - an expression is not beautiful because it is well done, but it is well done because it is beautiful. And the emotion cannot be thrown back by scornfully calling it 'hedonism' and considering it inferior to the main intellectual activities; because the feeling for beauty is one of the most superior activities of the spirit and it is in relationship with religious emotions." Philosophy belongs to theory, art belongs to emotion. "They have the same starting point but their ways are diverging and their aims are controversial." [7, p. 640]

Another specialty is that art is always idealizing and the basis of this idealization in the meaning of the perfect form, can be found in the world of memories.

The spiritual phenomenon which is closest to the artistic recollection is the dream, but this kind of memory misses all kinds of practical tendencies. Contrarily, the memory of the artist is active and autonomous, and transforms the sensational experience (sensation) into a pure approach in a way that changes the perception by removing the present - or changing it to the past. Among others, the difference between the two ways of recollection is that one of them has the main goal and dominant motif focusing on memory itself, while the other's main goal and dominant motif are primarily sensation and perception.

In art, clear images of memory can be found independent from practice and reality and in greater richness than usual. Art aspires to escape from time and from eternity. "Those memories achieving their final form are like that moment of freedom, which the mystic experiences in his ecstasy when being liberated from existence he arrives to existence itself. However, these moments out of time and eternity are only temporary for the mystic 
as well - this is their biggest paradox.' 5

Similarly to the mystic, the artist can also be part of timelessness and eternity by the finality of the completed forms, but being human, he always has to return to time. Nevertheless, during the creative process, present and past are at the same distance for the artist, and the name of this equal distance is form concludes Lajos Fülep.

"Form - says Fülep - is not formality but the essence of things." The deepest and most permanent part of things: the relation and unity of their element, and this is the "constructive factor". Reality is the sequence of moments; form is the ideal co-existence of moments: "Only art creates complete and final things, such phenomena that are the direct expressions of their ideas. (...) The piece of art cannot be reality (it is beyond reality) not for but against it is illusion. (...) The unreality of art stands above illusion.” [7, p. 648]

So the metaphysical importance of art comes out with the use of form when it expresses the things beyond time, things that never expire; not just in abstract ideas like philosophy or religion but with the forms of phenomena created by art itself. That is to say - now with reference to one of the relevant statements of Fülep's essays on architecture, or even quoting it - "art is concrete" [10].

And with this statement we have finally arrived to the (concrete) theme of architecture and to the matter of the sensationalconcrete quality of architectural form. However, it is interesting that Fülep formulates this approach of the concreteness of (architectural) form in a compact, definition and, though it is in accordance with his recollection theory, it appears in a non-theoretical work. The title of his work written after the $2^{\text {nd }}$ World War is: Egy nagy lehetöség Budapest és az ország újjáépitésében [A great opportunity in the re-building of $\mathrm{Bu}$ dapest and the country]. The article suggests the Castle and the castle district of Buda to be developed into a university and cultural centre, and it starts with the definition of architecture. According to that "architecture, as all kind of arts, is based on the ground of concrete things: on the relation to people, nature, world, on the fact that everything existing can be a simple tool beyond being a mere object and can have a specific, unique and relevant meaning that can only be seized, experienced and expressed in the completeness of the concrete relation. (...) Within this generality, architecture is special for not only focusing separately on this or that aspect of reality, not only on this or that field of reality, not only on human or nature, not only on spiritual life or the richness of natural phenomena, not only on events and processes, emotions or thoughts, not only on impressions. But in it - (in architecture) - the concrete human attitude,

\footnotetext{
$5 \sqrt{7}$ p. 644] - the phrasing can remind us of a similar sentence of Émanuel Lévinas on art (which text is part of the train of thoughts with a partly opposing end result): "this is a way of living where nothing is unconscious, but where a consciousness, paralyzed in its freedom, is playing - and it becomes completely loose in this play.." The expression of "wakeful dream" is also in harmony with the approach of Fülep.
}

presumed by and being the basis of all the above, appears on its own, it undertakes and make use of the part-potentials; however, always as a specific, most general attitude. Thus architecture's forms of presence are the categories - existing at other places too - in their most general definition: space, mass, material, form, strength, weight, statics, dynamics, scale, rhythm, stillness, motion, light, shadow and so on. But in general and concrete: it is a good metaphor for the fact that the human's relation can be concrete to a general category as well, we can find such kinds of relation not only in geometry, in physics or in the theoretical fields. [11 p.371]

So indirectly it is all about the creative memory's quality again which determines the form-creation - about that quality which establishes the intuition of recollection and in this way creates the sensual-concrete (architectural) form. Perhaps as an analogy with the contemporary architectural approach, Peter Zumthor also emphasizes this sensual-concrete character of form - just as he stresses elsewhere the role of memory in architectural forming.

"I find buildings again and again, that are created lavishly seeking after special forms. The architect who created this thing is not present but still he is talking away to me about all the details of the house, without any stop; and he says the same thing over and over, thus it becomes indifferent to me in a minute.

Good architecture has to rise up people, let them live and experience the house and not just talk men's heads off.

Why, I often wonder, is the obvious but difficult solution so rarely tried? Why do we have so little confidence in the basic things architecture is made from: material, structure, bearing and being borne, earth and sky, and confidence is spaces that are really allowed to be spaces - spaces whose enclosing walls and constituent materials, concavity, emptiness, light, air, odour, receptivity and resonance are handled with respect and care?

I personally like the idea of designing and building houses from which I can withdraw at the end of the forming process, leaving behind a building that is itself, that serves as a place to live in and a part of the world of things, and that can manage perfectly well without my personal rhetoric.

To me, buildings can have a beautiful silence that I associate with attributes such as composure, self-evidence, durability, presence, and integrity, and with warmth and sensuousness as well; a building that is being itself, being a building, not representing anything, just being.

(...) The reality of architecture is the concrete body in which forms, volumes and spaces come into being. There are no ideas except in things. This is the hard core of beauty." 6

With his statement - "the reality of the building is its own body”, Zumthor basically finds the spatial and formal concrete-

6 [17]; and he talks about the role of memory - of course in an indirect way in the film on the bath of Vals. Here he says the design process can be interpreted as the development of the details of the building's first appearing image, and the result of this development is the work of art, the form of building correct in every detail. 
ness of architectural creation determinative again, as a result of spacing and forming. He also speaks about the sensational and concrete, non-theoretic character of creation, similarly to Lajos Fülep.

At the same time, the concreteness of the art work and art in general - including architecture -has another meaning, i.e. quoting Gadamer - "the work of art addresses us on its own and not as the transmitter of a message." So the content and meaning, which is revealed in the piece of art and speaks to us, cannot be seized solely with notions.

The work of art carries not just an intellectual orientation which can be conceptually understood, consequently - ad absurdum - it cannot be replaced. "The work of art, being irreplaceable, works not just as the carrier of the meaning - because it would mean it was possible to transfer the meaning to other carriers - writes Gadamer. On the contrary: the importance of the work of art is based on its presence."

The above becomes even more obvious when the work of art is interpreted as formation; since, according to Gadamer, the formation-like character of a work of art - here we should add: especially in case of an architectural work - reveals the "skip" which divides the design and construction process from the succeeding result.

This "skip" can separate the creator - just as everyone else - from the creation or formation of his own work, which "is present for the good of all, it is available for the one who approaches it, and it is visible in its 'capacity'. The skip represents the work of art in its individuality and irreplaceablility."

Due to its sensual, concrete, indispensable and irreplaceable reality in the present and due to its formation-like quality, the work of art encloses the intellect into such a solid shape - we can say form - which on the one hand preserves, opens up, proclaims and makes unhidden the intellect-relations fixed in the work of art, but on the other hand it hides and covers them. "Besides the openness - and inseparably from it - there is the covering and hiding, which are due in part to human limitations - says Gadamer. This philosophical understanding - which restricts the idealism from clear integration of meaning - has another semantic content, namely that there is more in the artistic creations than the message which can be experienced as an undefined meaning." [13]

Continuing this train of thought, we could easily arrive at one of the most important categories in the forming and form creation in fine art and architecture, namely, the visual, plastic, architectonic - or rather to visual-plastic-architectonic - approach, but in the course of the present essay we can only refer to it and emphasize that the category came into existence partly on the basis of Fülep's recollection-theory.

In my opinion, the matters of recollection, sensual-concrete form and visual-plastic-architectonic way of thinking, the scientific-historical genesis of the concepts and categories and their relation to the other would need a more detailed analysis, phrasing and processing. And it would also be important to in- tegrate these theories into the Hungarian architectural thinking in order to avoid the dominance of irrelevant and secondary theories from the architectural approach's point of view, born in the mesmerization of the momentary topicality.

Essentially the same thing happens with the most important study on architecture by Lajos Fülep par excellence, called: Célszerüség és müvészet az építészetben [Expedience and art in architecture] -, namely that it is not an integrated part of the architectural thinking or the reasoning on architecture [10].

The article was written in 1944, on the request of Jenó Padányi Gulyás, architect and editor of the periodical "Architecture", but since the journal was stopped because of the war, only the first part of the essay had been published. However, along with the text of the first part, the sketches of the whole or at least the second part of the article have subsisted too. 7

The writing examines the influence of the relation between expedience and art on the identity of modern architecture. "The relation between expedience and art, their interference remains a problem for today's architecture" - states Fülep right at the beginning of his study. Then he continues: "It has always been a challenge, sometimes harder, sometimes easier but always possible to be fulfilled. (...) If it was a challenge we could unequivocally define its content which would lead to the method of implementation by necessity. But we cannot do it. (...) That's why it remains a problem." [10, p. 342]

As we could have already seen, the identity of architecture reflecting in different forms to the state of periods and societies - has its roots in the ground of the (artistic) concreteness of the (architectural) form that is able to evoke the most general things in a way irreplaceable by any other concepts. But it seems that this architectural identity, rooting in the ground of concreteness and being realized in existence, fell prey to the approach of modern times formed by the mesmerization of utopias and focusing on the technical progress and the concept of innovation. This is clear when in technology, the "empty-formal possibility of canbe-this-way, can-be-that-way" is manifested, and again because in this period, the idea and fact of freedom bear a negative connotation - "it contains the liberation under something instead of the freedom of becoming something” [10, p. 354,360].

It is interesting because it is modern! In retrospect - looking back not only to the period of classical modern architecture which was also examined by Lajos Fülep, it seems that this imperative had pervaded the history of architecture of the century and its forming practice even as postmodernism has opposed the reductionalism of the modernist expedience "besieging the peeks of time" (less is more) with the eclecticism simulating the significance of "everything can be quoted" (less is bore).

It seems, one of the reasons for the above is that in both cases, and nearly in all cases of modern cultural and architectural paradigms, the concept of innovation became the one and

7 [10] ; According to some opinions the ,fragments of the 2nd part" may be considered as the sketches for the whole text. 
only legitimate basis of value, forcing the production of novelties and distinctions, namely differences in form and content. All then result from both the cultural overproduction speeded up by technology and from the influence of the innovative logic of technology on the spirit of the age. In this period, the notion of novelty plays the role of the "cultural-ecological censorship" which was played by the concept of quality in pre-modern times [14]. As a consequence, the converse relation of quality and modernity - i.e. it is interesting because it is modern - has become dependent upon novelty once and for all (and to the extremes); finds its identity in the concept of "differing" and "something else", which are neutral notions from the point of view of quality.

Although, art can be only modern - stated Lajos Fülep at that time, analyzing the status of architecture forced momentarily into expedience, and said: "It is not valuable for being modern but it is modern for being valuable. Art is concrete.(...) So the standard of modernity is not the standard of fashion or to "go with the flow of time", but it is an irreplaceable and indispensable chance." As in Hegel's opinion on philosophy, Fülep finds that art - or the "modernity" of art - is actually the realization of the era. For realizing the period a spiritual-intellectual content is needed, which stands for itself and which is not only a moment of technology and expedience but also belongs to the intellect; "when the place of the intellect is not determined by technology, but vice versa the place of technology is determined by the intellect." [14]

Fülep draws the last conclusion of his train of thoughts as follows: in this situation, which owes its essence to historical reasons, not all of the things, which could have become art before, can become art. In case architecture cannot be "royal art" in the way it was in historical times, therefore it may be simply practical too since expedience is not against art. "Everything, rather than doing bad art. And in practicality, at least the place should be appreciated and made to be a tradition since there is nothing else. And in this way art can rise from expedience too. At the very first time, and from that time on, architecture was born not when art became practical but on the contrary, when the practical became art. But it could and can never originate from the tyranny of expedience. (...) However, in a wider sense of practicality it is not only material but also intellectual expedience. Where not only the physical body feels at home and moves about freely but also the intellect and spirit. (...) This law can predominate even now if we don't force, don't twist and don't cripple it. The natural law works “on its own”, i.e. without us the spiritual law works through us." 8

The words written in the first part of the $20^{\text {th }}$ century are still topical today, and the content coheres with the writings previously mentioned which worked up or only mentioned architecture and were written before (and partly after) Fülep's. Here

${ }^{8}[10$ : fragments of the 2 nd part. the theoretical centre is not the art-historical interpretation of the role of creative memory in the determination of form, nor the matter of sensual-concreteness of form. It is much more, in harmony with the former ones, the right relation between the concept of modernity and (artistic) value and the emerging problems concerning the relation of practicality and art, especially the conceptual problem concerning technical and intellectual expedience.

Beside his art-theoretical and architecture-theoretical approach, Fülep has achieved significant results in the art historical interpretation of architecture. In his study, Magyar épitészet [Hungarian Architecture], a chapter in his work on Hungarian Art is perhaps the best well known. This discusses the Hungarian architecture as part of Hungarian art with a historical aspect and contains theoretical arguments as well. It could be known for its thorough and even today valid interpretation of Ödön Lechner's architecture - though architects are seldom familiar with it, despite it being the first in the plastic explanation of the autochthon qualities of the whole of Hungarian art [9].

In the framework of the present essay, it is worthwhile to emphasize some sentences from the study's critique of Lechner, where the relation between universal and national art, and accordingly some references to the interpretation of style, become distinct. Namely, the antagonism of Lechner's architectural attitude, which, however, led to a uniquely successful solution; and this way it confirmed that there is not a "royal way" in art which could be theoretically defined beforehand since - among other reasons - "art is concrete".

"Finally Lechner, who was extremely familiar with all kinds of styles, ended up in rejecting all styles - writes Fülep - and all relations to style; he disapproved of the regular return to primitive styles in order to reach the plane - the mere wall. And when he found it and rejected everything in order to create space, a pure space, then the chance for a new architecture appeared. (...) The same happened in the West, but for different reasons and aims. In western countries, architects returned to flat walls, as they were free from all embarrassing fripperies and because new building materials forced them to do so. Lechner's reason was to bring out the vernacular forming-language in the flat element of the wall. Searching for the national, he found international, looking for Asian he found European, for special, the universal and for ancient the modern and current style. The westerner's understanding of the problems in constructing buildings has always been an obvious demand on him: he did not need to find the European problem of modern building but the way leading to it and the possibility of such a solution in which the universal can be realized through national and national through universal. This was his specific challenge..." [12, pp 52-53]. And so on. Although some have the opinion that the matter of the relationship between national and universal is not a problem anymore in architecture and art; although this is a doubtful approach, the clarification of this historically conflicting relationship would be interesting in retrospect. This could 
be cleared up perhaps with the help of Lajos Fülep's thoughts, which are just as valid today, at least for the sake of the "intellectual expedience" of contemporary Hungarian architecture.

The concepts appearing in these studies are built upon one another, and sometimes their relationship requires interpretation. This suggests that the categories playing the main role in the different essays could be organized into a coherent theory or a theoretical construction. Furthermore, the elements of this intellectual construction could create a curve from art philosophical erudition to art historical intuition. Or they could make it if posterity found the knowledge worth studying and thus learned that which is accumulated in the "a bit forgotten " art-theoretical, architectural theoretical and historical works of Fülep. This work could bear not only a scientific-historical significance but also the cognition of Fülep's intellectual horizon could be very inspiring in architecture and in thinking about architecture.

\section{References}

1 Croce B, Estetica come scienza dell'espressione e linguistica generale, Sandron, Palermo, 1902.

2 _ A szellem filozófiája - válogatott írások, Gondolat, Budapest, 1987.

3 Fülep L, Paul Cézanne, Szerda 1 (31. Oct. 1906), no. 5, 254-256.

4 _ Paul Cézanne, Múvészet 6 (1907), no. 3, 154-159.

5 _ Cézanne és Gauguin, A Hét XVIII (12. May 1907), no. 19, 318-319.

$6 \_$L La Memoria nelle Creazione Artistica, Bolettino della Biblioteca Filosofica III (1911. Febbrario Anno), no. XIX, 402-408.

7 , Az emlékezés a múvészi alkotásban, A Szellem I (March 1911), no. $1,56-90$.

8 , Dante essay - together with the writings Petrarca, Humanism, Ariosto, Machiavelli and Tasso, Világirodalom.

$9 \_$, Magyar építészet, Nyugat (16 April 1918).

10 _ Célszerüség és müvészet az építészetben, Építészet.

11 _ Egy nagy lehetôség Budapest és az ország újjáépítésében, Forum III (Sept. 1948), no. 9, 690-701.

12 _ Magyar Múvészet, Corvina, Budapest, 1971.

13 Gadamer H G, A szép aktualitása - A múvészet, mint játék, szimbólum és ünnep, T-Twins Kiadó, Budapest, 1994.

14 Groys B, A tautológiáé a jövó, Az utópia természetrajza, translated by Sebők Z, Kijárat Kiadó, Budapest, 1997.

15 Lőrincz E, Fülep Lajos és a "Bécsi Iskola”, Fülep Lajos emlékkönyv cikkek, tanulmányok Fülep Lajos életérôl és munkásságáról, 1985, pp. 311 321.

16 Takács J, Benedetto Croce múvészetelméleti nézetei, Filológiai Füzetek 32 (1981).

17 Zumthor P, The hard core of beauty, Du, Die Zeitschrift der Kultur 615 (Mai 1992), no. 5, 68-69. 